\title{
PERKEMBANGAN RISET AKUNTANSI NILAI TAMBAH SYARIAH
}

\author{
Rohmat Hidayatulloh dan Sepky Mardian \\ Sekolah Tinggi Ekonomi Islam SEBI, Indonesia \\ Jl. Raya Bojongsari No. 63, Bojongsari, Depok, Jawa Barat \\ Email: rohmathidayatulloh2@gmail.com
}

\begin{abstract}
This study reviews research around sharia Value Added/Value Added (VA) accounting. This study uses descriptive qualitative analysis based on 100 samples of publication of selected journal articles related to VA, both national and international journals. The published samples of journal articles were published for the last 25 years from 1994 to 2018. The results show that value-added accounting research is still dominated by the theme of discussion (issues) about Value Added Statement/Reporting (54\%), followed by discussion issues regarding Value Added (22\%), then issues of institutional discussion (15\%) and about management (9\%). Indonesia, United States, United Kingdom and South Africa are the most studied areas, while the largest publication areas are Indonesia, United States, United Kingdom and India. Furthermore, comparative quantitative research and mixed methods are still less than the qualitative research approach. In addition, VA development periodization shows that each year it continues to grow from the initial sharia Value Added statement (SVAS) model, SVAS reconstruction, SVAS critical analysis, analysis of SVAS implementation, to improvement of the SVAS model.
\end{abstract}

Keywords: Value Added; Added Value Research; Value Added Issues

\begin{abstract}
ABSTRAK
Penelitian ini mengulas penelitian seputar nilai tambah syariah (syariah value added/SVA). Penelitian ini menggunakan analisis deskriptif kualitatif berdasarkan 100 sampel publikasi artikel jurnal terpilih terkait SVA, baik jurnal nasional maupun internasional. Sampel artikel jurnal yang diterbitkan diterbitkan selama 25 tahun terakhir dari tahun 1994 hingga 2018. Hasil penelitian menunjukkan bahwa penelitian akuntansi nilai tambah masih didominasi oleh tema diskusi (isu) tentang Pernyataan/Pelaporan Nilai Tambah (54\%), diikuti dengan pembahasan isu-isu Value Added (22\%), kemudian isu-isu diskusi kelembagaan (15\%) dan tentang manajemen (9\%). Indonesia, Amerika Serikat, Inggris, dan Afrika Selatan merupakan wilayah yang paling banyak diteliti, sedangkan wilayah publikasi terbesar adalah Indonesia, Amerika Serikat, Inggris, dan India. Selanjutnya, penelitian kuantitatif komparatif dan metode campuran masih kalah dibandingkan dengan pendekatan penelitian kualitatif. Selain itu, periodisasi pengembangan VA menunjukkan bahwa setiap tahun terus berkembang dari model awal syariah Value Added statement (SVAS), rekonstruksi SVAS, analisis kritis SVAS, analisis implementasi SVAS, hingga penyempurnaan model SVAS.
\end{abstract}

Kata kunci: nilai tambah; riset nilai tambah; isu nilai tambah 


\section{PENDAHULUAN}

Akuntansi merupakan produk sejarah dan refleksi budaya, dalam perkembangannya akuntansi sangat dipengaruhi oleh alam dan lingkungan tempat akuntansi itu dikembangkan (Adnan, 1997). Akuntansi konvensional dipengaruhi oleh berbagai macam ideologi. Diantaranya pengaruh yang paling dominan adalah ideologi kapitalisme. Hal ini terlihat dari beberapa pendapat ahli akuntansi, Harahap (2001) menyatakan bahwa ilmu akuntansi konvensional yang berkembang saat ini dilandasi jiwa kapitalisme. Sebaliknya perkembangan ekonomi kapitalisme sangat dipengaruhi oleh perkembangan akuntansi konvensional. Bahkan Triyuwono (2001) mengatakan bahwa akuntansi saat ini adalah kapitalisme murni.

Terlihat jelas dalam laporan keuangan konvensional menekankan informasi pada laba atau pertambahan kekayaan pemilik. Kelemahan lain dari laporan laba rugi hanya menggambarkan hak atau kepentingan pemegang saham saja, bukan seluruh yang ikut terlibat dalam kegiatan perusahaan. Secara konsep saat ini diakui bahwa pertambahan kekayaan itu adalah usaha semua pihak, bukan hanya pemilik saham atau pengelola. Sehingga laporan tersebut akan lebih mencerminkan pengungkapan penuh (full disclosure) (Naswandi, 2009).

Manusia dan aktivitasnya (entitas) telah melakukan daya ubah cukup jauh di luar kemampuan daya dukung planet bumi. Terjadinya eksploitasi alam (resources) demi pencapaian kepentingan ekonomi (profit). Mengabaikan aspek sosial dan lingkungan, menimbulkan krisis global yang serius, yaitu suatu krisis kompleks dan multidimensional.

Dunia Barat mengakui bahwasannya perlu adanya konsep tanggung jawab sosial dan lingkungan. Menurut Elkington dikutip dari Suyudi (2010) teori TBL (Triple Bottom Line) pada bukunya "Cannibals with forks, the triple bottom line of twentieth century business". Elkington berpendapat jika sebuah entitas ingin mempertahankan kelangsungan hidupnya, maka harus memperhatikan triple-P (People, Planet and Profit). Namun konsep ini, dinilai belum sepenuhnya mengghilangkan sisi kapitalistik. Karena tidak adanya pertanggungjawaban yang lebih kompleks bila diterapkan dalam perusahaan berlabel syariah (pertanggungjawaban kepada Tuhan).

Baydoun \& Willett (2000) mengembangkan sebuah teori tentang pelaporan keuangan lembaga yang beroperasi dengan prinsip syariah, yang dinamakan Islamic Corporate Reportings (ICRs) dan menyarankan laporan nilai tambah sebagai tambahan laporan keuangan. Berbeda dengan laporan laba rugi, laporan nilai tambah mengarah pada kepentingan lebih luas dalam bentuk distribusi pada seluruh stakeholder (karyawan, masyarakat, pemerintah dan lingkungan). Diadopsinya laporan nilai tambah dalam salah satu laporan keuangan syariah, dianggap telah sesuai dengan prinsip-prinsip akuntansi syari'ah (Triyuwono, 2007).

Aliran-aliran yang berkembang dalam riset Sharia Value Added (nilai tambah syariah) terus berkembang sampai ke arah pengkayaan teori. Dua arus utama pemikiran dalam akuntansi syariah telah sampai pada pemikiran diametris, antara Syariah Enterprise Theory (SET) dan Entity Theory (ET). 
SET yang dibangun berdasarkan metafora amanah dan metafora zakat, lebih menghendaki keseimbangan antara sifat egoistik dan altruistik dibanding dengan ET. Sementara ET lebih mengedepankan sifat egoistiknya daripada sifat altruistik (Triyuwono, 2007).

Sedangkan dari segi pelaporan nilai tambah mempunyai dua pendekatan yaitu: Additive Methode dan Subractive Methode. Dua pendekatan ini dipraktikkan secara umum di negara Jerman, Prancis, Inggris dan Australia, walaupun belum ada standar yang baku mengaturnya. Sementara di Indonesia karena tidak adanya standar yang mengatur dan mengharuskannya, maka penerapan laporan nilai tambah belum lazim dilaksanakan (Pohan, 2010). Penerapan laporan nilai tambah diterapkan sebagai pendamping laporan laba rugi entitas syariah dan publikasinya diserahkan kepada entitas syariah yang bersangkutan.

\section{TELAAH TEORITIS}

\subsection{KONSEP NILAI TAMBAH (VALUE ADDED) DALAM AKUNTANSI}

Value Added adalah ukuran kinerja entitas ekonomi yang memiliki sejarah panjang pada aplikasinya dalam ilmu ekonomi. Value Added merupakan konsep utama dari pengukuran income. Konsep Value Added secara tradisional berakar pada ilmu ekonomi makro, terutama berhubungan dengan perhitungan pendapatan nasional yang merepresentasikan nilai tambah perekonomian nasional dalam periode spesifik (Mulawarman, 2009a). Dalam penelitian lain nilai tambah menurut John Sizer menyebutkan bahwa nilai tambah adalah kekayaan perusahaan yang tercipta atas usaha yang telah dilakukan oleh pemilik dan karyawan selama satu periode. (Yogesha \& Mahadevappa, 2014).

Laporan nilai tambah ditafsirkan sebagai informasi tambahan untuk memberikan pandangan yang adil dan jujur kepada para stakeholder, dimana di dalamnya terdapat laporan kontribusi dari masing-masing pihak yang terlibat dalam proses penciptaan nilai tambah bukan hanya pemilik saham. Konsep nilai tambah berasal dari implementasi Gross National Product (GNP) ekonomi makro, kemudian diterapkan dalam dunia akuntansi (Mulawarman, 2009a).

\subsection{SHARI'ATE VALUE ADDED STATEMENT (SVAS)}

Mulawarman (2009a) mendefinisikan SVAS (Shari'ate Value Added Statement) adalah pertambahan nilai (zakat) material baik finansial, sosial, dan lingkungan yang telah disucikan mulai saat pembentukan, hasil sampai distribusinya. Semua itu harus halal dan tidak mengandung riba (lahiriah), serta thoyyib (batin).

Pertama, proses pembentukan nilai tambah dalam batas-batas yang diperbolehkan syara (halal) dan bermanfaat (thoyyib). Dengan kata lain aktivitas ekonomi yang melanggar ketentuan adalah haram, Kedua, pertumbuhan harta dan mekanisme usaha harus dilakukan untuk 
menghilangkan sifat berlebihan dalam memperolehnya dan menjalankan aktivitas usaha yang bebas riba. Sedang dari aspek finansial, bebas riba adalah kerja sama berdasarkan prinsip jual beli maupun bagi hasil. Dari aspek sosial dan lingkungan, reduksi riba dilakukan dengan melakukan relasi sosial dan lingkungan alam secara pro-aktif berdasarkan prinsip shodaqah. Ketiga, distribusi VA harus dilakukan secara optimal untuk kebaikan bersama, merata, dan tidak saling menegasikan. Sekecil apapun keikutsertaan harus dicatat dan diakui sebagai potensi untuk mendapatkan hak pendistribusian VA.

\subsection{ISLAM MEMANDANG LAPORAN NILAI TAMBAH}

Laporan nilai tambah sejalan dengan konsep Islam terutama dalam hal keadilan, semisal QS An-Nisa [4] ayat 135 sebagai berikut:

Artinya: "Wahai orang-orang yang beriman, jadlah kamu orang yang benar-benar penegak keadilan, menjadi saksi karena Allah biarpun terhadap dirimu sendiri atau ibu bapa dan kaum kerabatmu. Jika ia kaya ataupun miskin, maka Allah lebih tahu kemaslahatannya. Maka janganlah kamu mengikuti hawa nafsu karena ingin menyimpang dari kebenaran. Dan jika kamu memutar balikkan (kata-kata) atau enggan menjadi saksi, maka sesungguhnya Allah adalah Maha Mengetahui segala apa yang kamu kerjakan."

Laporan nilai tambah merupakan laporan yang lebih bersifat adil. Dimana di dalamnya dilaporkan kontribusi masing-masing pihak yang terlibat dalam proses penciptaan nilai tambah, bukan hanya kontribusi pemilik modal. Kontribusi karyawan, pemilik, fasilitator pembiayaan, pemerintah ditunjukkan dalam laporan (Harahap, 2001).

\section{METODE PENELITIAN}

Penelitian ini menggunakan data sekunder berupa dokumen hasil penelitian pihak lain berbentuk artikel jurnal yang dipublikasi. Terdapat 100 judul penelitian terkait akuntansi nilai tambah (Value Added) yang dikumpulkan sebagai data, yang diperoleh dari publikasi nasional dan internasional secara online dalam kurun waktu 25 tahun terakhir mulai dari 1994-2018.

Metodologi yang digunakan dalam penelitian ini menggunakan pendekatan metode kualitatif deskriptif, studi literatur terhadap 100 sampel artikel jurnal tentang akuntansi nilai tambah. Data yang dianalisis tidak untuk menerima atau menolak hipotesis (jika ada). Hasil dari analisis tersebut berupa deskripsi atas gejala-gejala yang diamati dan tidak harus berbentuk angka-angka atau koefisien antar variabel (Subana \& Sudrajat, 2005).

Penelitian ini dilakukan dengan metode skimming yaitu teknik membaca cepat dengan tujuan untuk menemukan topik dan ide pokok paragraf tertentu tanpa harus membaca artikel jurnal secara keseluruhan. Dalam membaca, skimming dan scanning merupakan dua teknik yang berbeda. Keduanya sama-sama merupakan teknik membaca cepat, perbedaan 
terletak pada tujuannya. Scanning biasa digunakan untuk menemukan kata atau frase tertentu secara spesifik sedangkan skimming tidak hanya kata atau frase tetapi juga topik dan ide pokok sebuah paragraf.

Metode sampling dalam penelitian ini menggunakan metode sampling non probabilitas purposive. Sample bertujuan (purposive) untuk memahami informasi tertentu. Sample ini dapat dikelompokan menjadi sample keputusan (judgement) yang memilih anggota-anggota sampel sesuai dengan beberapa kriteria. Kriteria yang dimaksud dalam penelitian ini yaitu publikasi artikel jurnal terkait perkembangan riset akuntansi nilai tambah syariah dari tahun 1994-2018.

\section{HASIL DAN PEMBAHASAN}

\subsection{JUMLAH PUBLIKASI PER TAHUN}

Pada pembahasan bagian ini menjelaskan jumlah publikasi artilel jurnal dari tahun 1994 hingga 2018. Terdapat 100 sampel artikel jurnal yang terpublikasi baik jurnal nasional maupun internasional yang berhubungan dengan Value Added/akuntansi nilai tambah syariah.

Grafik 1 menjelaskan distribusi artikel jurnal dikategorikan berdasarkan tahun penerbitan. Hasil observasi menunjukkan jumlah artikel jurnal terpublikasi bervariasi dari tahun 1994 hingga 2018 dengan range 2 hingga 10 jurnal. Tahun 2016 merupakan tahun dengan sampel artikel penelitian terbanyak yaitu 10 artikel jurnal. Sedangkan pada tahun 1999, 2002, 2004, 2005 dan 2006 jumlah penelitian seputar akuntansi nilai tambah yang dijadikan sampel masing-masing hanya berjumlah 2 artikel jurnal. Lebih lanjut, detail jumlah sampel untuk masing-masing tahun sebagai berikut; pada 2015: 9 artikel jurnal, 2011: 7 artikel jurnal, 2018, 2014, 2013, 2008 \& 1998: 5 artikel jurnal, 2009, 2003 \& 2006: 4 artikel jurnal, 2017, 2012, 2010, 2007, 2001, 2000, 1997, 1995 \& 1994: 3 artikel jurnal.

Grafik 1. Jumlah Publikasi per Tahun

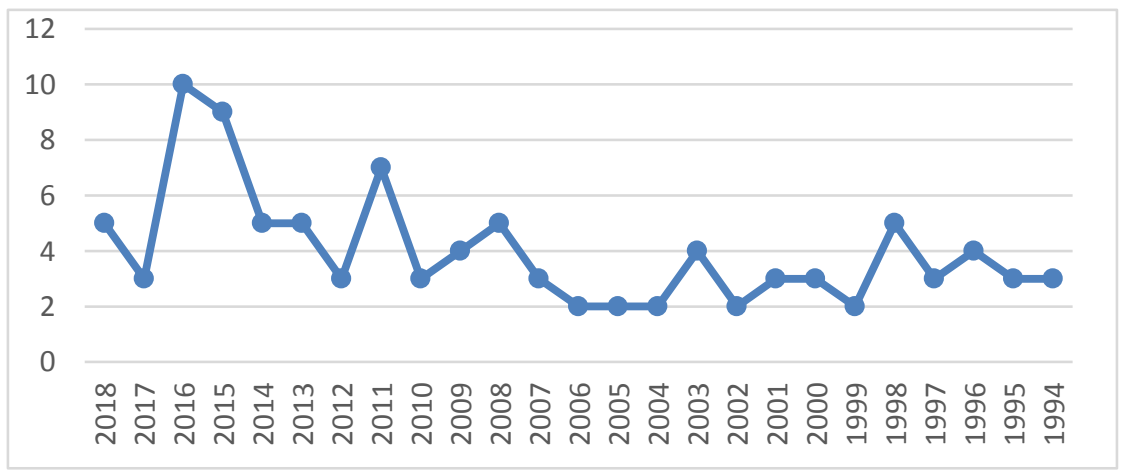

Sumber: Penulis 


\subsection{JENIS PENELITIAN DARI MASING-MASING PUBLIKASI}

Grafik 2 menunjukkan jenis (tipe) penelitian yang digunakan untuk setiap publikasi jurnal yang diamati. Menurut Serdarmayanti \& Hidayat (2011), secara umum jenis penelitian jika dilihat dari tujuannya terdapat tiga tipe penelitian yaitu deskriptif, eksperimental, dan penelitian eksplanatoris/eksploratif.

Pertama, penelitian deskriptif adalah suatu metode dalam pencarian fakta status sekelompok manusia, suatu obyek, suatu kondisi, suatu sistem pemikiran ataupun suatu peristiwa pada masa sekarang dengan interpretasi yang tepat. Kedua, penelitian eksperimental yaitu penelitian yang berusaha mencari pengaruh variabel tertentu terhadaap variabel lain dengan kontrol yang ketat. Dan ketiga, metode penelitian eksploratif yaitu metode penelitian yang dilakukan untuk mencari sebab atau hal-hal yang mempengaruhi terjadinya sesuatu.

Dari Grafik 2 dapat diketahui bahwa jenis metodologi penelitian yang terbanyak digunakan dari 100 sampel artikel jurnal yang terpublikasi baik jurnal nasional ataupun internasional, selama perode tahun 1994 hingga 2018 yaitu jenis penilitian deskriptif 44 Jurnal, kemudian diikuti oleh jenis penelitian eksperimental 30 Jurnal dan yang terakhir yaitu jurnal yang menggunakan penelitian eksploratif sebanyak 26 artikel jurnal.

Grafik 2. Jenis Penelitian dari Masing-Masing Publikasi

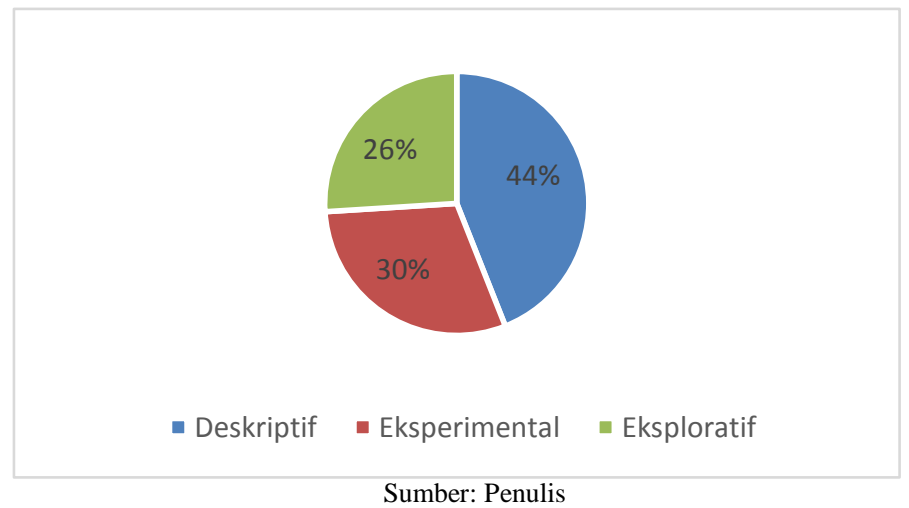

\subsection{JENIS DATA PENELITIAN DARI MASING-MASING PUBLIKASI}

Berdasarkan Serdarmayanti \& Hidayat (2011), ada 3 jenis data penelitian yaitu pendekatan kualitatif, pendekatan kuantitatif dan pendekatan metodologi campuran (mixed method). Grafik 3 menunjukan metodologi yang digunakan untuk setiap artikel jurnal yang terpublikasi tahun 1994 hingga 2018. Dalam obsevasi ini, pendekatan penelitian yang terbanyak digunakan adalah pendekatan kualitatif sejumlah 56 artikel jurnal, kemudian penelitian dengan pendekatan kuantitatif sejumlah 42 artikel jurnal dan terakhir yaitu jurnal yang menggunakan pendekatan kombinasi (mix method) sejumlah 2 artikel jurnal. 
Dari hasil analisis ini tidak salah jika kita menilai bahwa penelitian seputar akuntansi nilai tambah/Value Added (VA) masih berada pada posisi sebagai gagasan atau konsep belum ke tahap implementasinya karena belum adanya aturan baku yang mewajibkan penerapannya. Namun, perlu dipahami bahwa itu bukanlah sebuah kesalahan. Karena VA baik dari sisi gagasan maupun implementasinya penting untuk diteliti. Penyebab penelitian VA lebih banyak pada pendekatan kualitatif bisa jadi sebab belum ada persediaan data kuantitatif yang "cukup baik". Karena penelitian kuantitatif yang baik sangat membutuhkan data yang akurat.

Grafik 3. Pendekatan penelitian Masing-Masing Publikasi

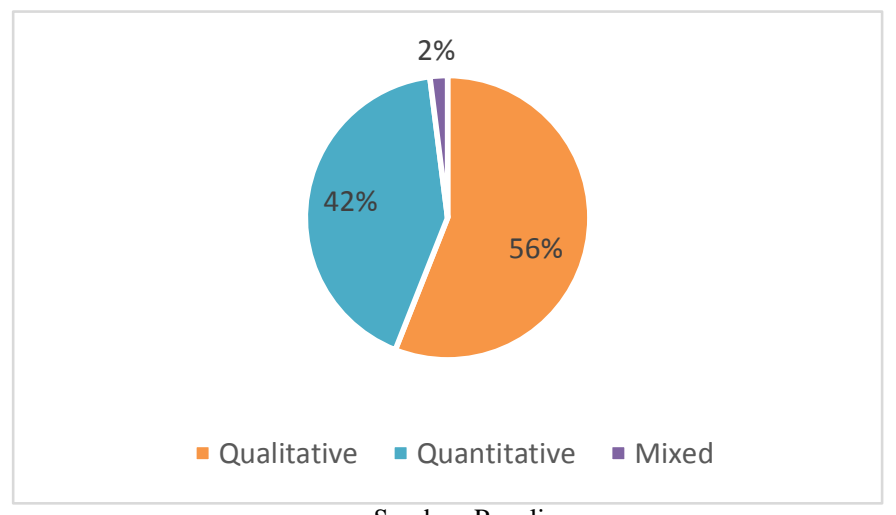

Sumber: Penulis

Terkait jenis metodologi penelitian kuantitatif yang digunakan dalam 42 artikel jurnal terpublikasi dari 100 sampel artikel jurnal, dari hasil observasi metode yang paling banyak digunakan adalah sebagai berikut: metode Independent Sample T-test/Uji Beda (13 artikel jurnal), Deskriptif Statistik - Kuisioner (11 artikel jurnal), Single - Multiple Regression Analysis (7 artikel jurnal), Data Envelopment Analysis/DEA (5 artikel jurnal), dan metode lainnya antara lain Partial Least Square/PLS, Probability Unit/Probit, Structural Equation Modeling/SEM, Analytic Network Process/ANP yang masing-masing satu artikel jurnal.

\subsection{SUBJEK JURNAL AKUNTANSI NILAI TAMBAH (SYARIAH)}

Grafik 4 menunjukkan subjek pembahasan masing-masing artikel jurnal terkait dengan Value Added/akuntansi nilai tambah syariah berdasarkan publikasi jurnal selama tahun 1994 hingga 2018. Adapun dalam observasi ini berdasarkan empat subjek yaitu terkait Institusi, Manajemen, Nilai Tambah (Value Added), Value Added Statement (VAS). Dari hasil observasi menunjukan subjek pembahasan terkait artikel jurnal akuntansi nilai tambah syariah terbanyak yaitu Value Added Statement/Reporting sejumlah 54 artikel jurnal, kemudian diikuti oleh subjek pembahsan mengenai Value Added 22 artikel jurnal, kemudian subjek pembahasan institusi 15 artikel jurnal, dan pembahsan subjek paling sedikit yatu tentang manajemen 8 artikel jurnal. 
Grafik 4. Subjek Pembahasan Jurnal Akuntansi Nilai Tambah Syariah

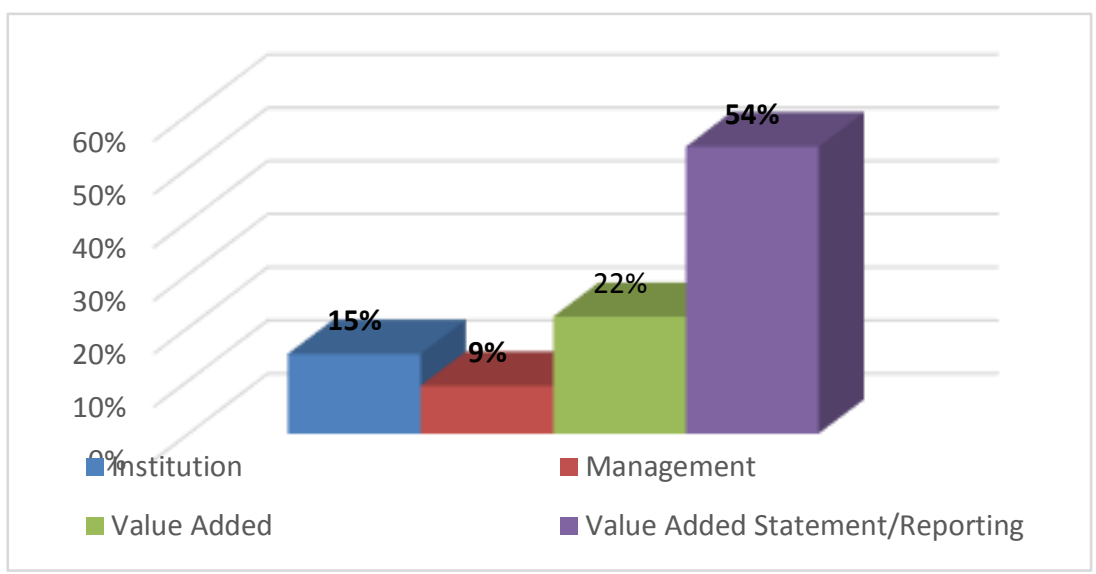

Sumber: Penulis

\subsection{AREA STUDI DAN PUBLIKASI BERDASARKAN NEGARA}

Gambar 1 menunjukkan daftar publikasi artikel jurnal berdasarkan letak geografis (negara). Terdapat 2 bagian dalam pembahasan ini yaitu lokasi objek studi 100 sampel artikel jurnal publikasi terpilih dan area publikasi artikel jurnal tersebut. Pada bagian pertama, mengenai lokasi objek atau area studi jurnal.

Gambar 1. Area Studi Berdasarkan Negara

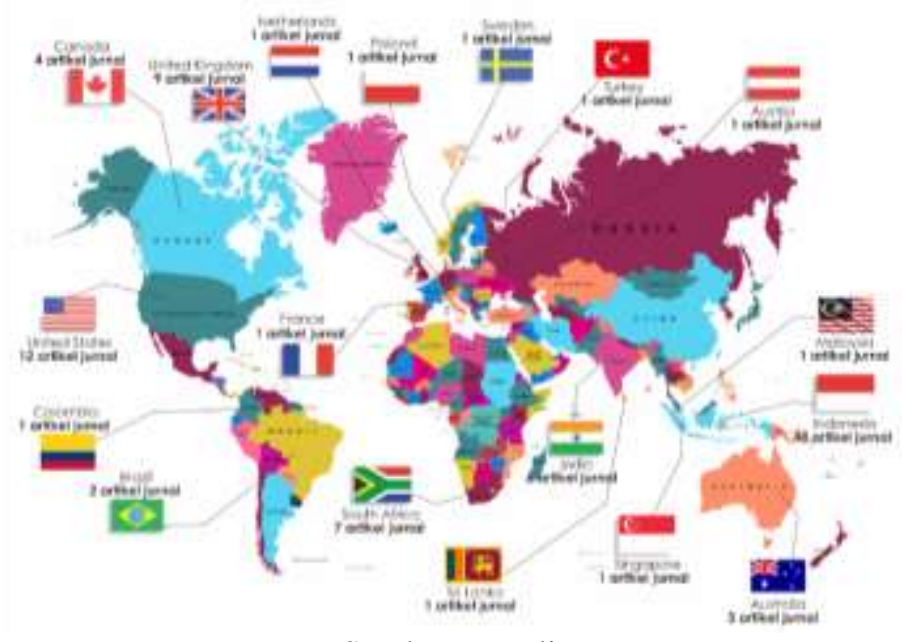

Sumber: Penulis

Dari 
Gambar 1 dapat diketahui bahwa Indonesia dan Amerika Serikat menjadi area studi terbanyak terkait penelitian Value Added yaitu sejumlah (48 artikel jurnal) Indonesia, (12 artkel jurnal) Amerika Serikat, Kemudian diikuti oleh Inggris ( 9 artikel jurnal), Afrika Selatan (7 artikel jurnal), di urutan ke-5 Kanada dengan (4 artikel jurnal), Australia (3 jurnal), Brazil (2 jurnal), Austria, Australia, Colombia, Malaysia dan negara lainnya (masingmasing 1 jurnal).

Senada dengan area studi, dari segi area publikasi artikel jurnal, Indonesia menjadi negara yang terbanyak publikasi yaitu sejumlah (44 artikel jurnal), Amerika Serikat (15 artikel jurnal), Inggris/United Kingdom (14 artikel jurnal), India ( 8 artikel jurnal), Belanda (5 artikel jurnal), Belanda (5 artikel jurnal), Australia (3 artikel jurnal), Brazil (2 artikel jurnal) dan sisanya dengan masing-masing 1 artikel jurnal antara lain; Negara Afrika Selatan, Austria, Jepang, Malaysia, Polandia, Rumania, Swedia, Swiss dan Ukraina.

Gambar 2. Area Publikasi Berdasarkan Negara

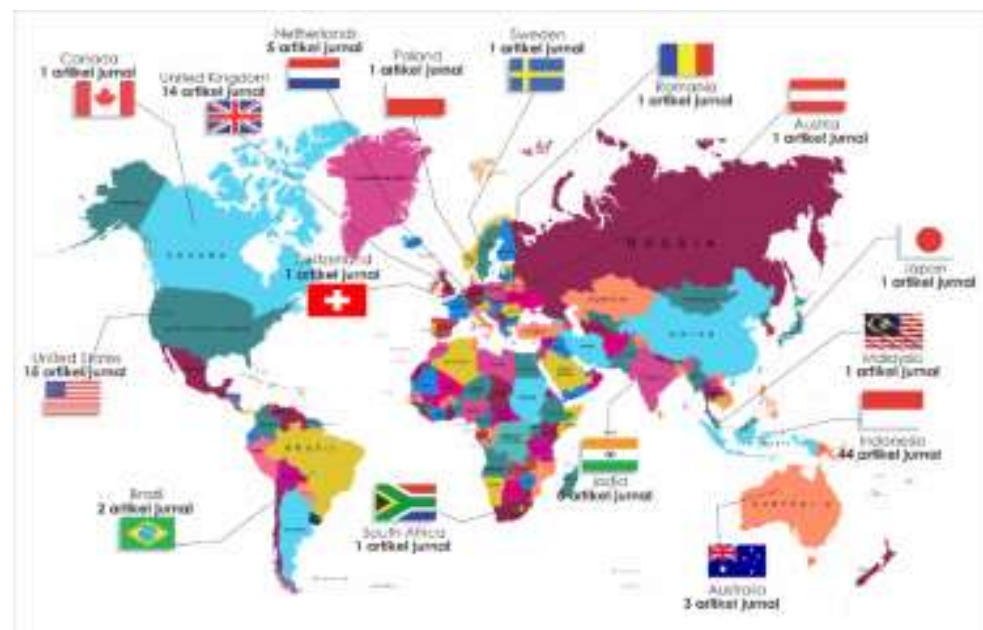

Sumber: Penulis

Indonesia, Amerika Serikat \& United Kingdom mendominasi baik dari segi area study dan publikasi, kemungkinan disebabkan dua faktor: Pertama, Indonesia adalah Negara dengan mayoritas penduduknya muslim, sehingga ketika muncul isu riset terkait sharia Value Added memberikan pandangan baru yang menarik untuk di teliti dengan kemungkinan diterapkannya pada perusahaan-perusahaan di Indonesia. Sementara Amerika Serikat dan Inggris jika ditelaah kembali di negara tersebut merupakan negara-negara yang mempopulerkan konsep VA (Value Added) sejak tahun 1970, sehingga riset-riset VA telah banyak dilakukan.

Kedua, Indonesia Amerika Serikat \& United Kingdom mendominasi sebagai negara yang paling banyak publikasi artikel jurnal terkai VA, karena kami menggunakan media internet yang berbasis di Indonesia. Tentu search 
engine mendeteksi dan mengutamakan penelitian nasional, kemudian merekomendasikan negara luar yang telah banyak mempublikasikan. Menariknya, jika dilihat penelitian VA hampir disetiap benua ada negara yang melakukan penelitian, ini adalah bukti eksistensi konsep Value Added yang menarik untuk dijadikan objek penelitian.

\subsection{RANKING JURNAL PUBLIKASI AKUNTANSI NILAI TAMBAH SYARIAH}

Adapun publikasi dari 100 sampel artikel jurnal yang berhubungan dengan Value Added terpilih bervariasi yaitu terdapat lebih dari 50 jenis jurnal. Dalam penelitian ini, IOSR Journal of Business and Management menjadi jurnal terbanyak dalam mempublikasikan jurnal yaitu sejumlah 4 jurnal, kemudian diikuti oleh JAKI Jurnal Akuntansi dan Keuangan Indonesia dan Journal of accounting research (masing-masing 3 jurnal), IQTISAD Journal of Islamic Economics, IUP Journal of Accounting Research and Audit Practices dan Social and Environmental Accountability Journal (masingmasing 2 jurnal), kemudian International Journal of GEOMATE, Global Journal of Business and Social Science Review, Proceeding PESAT, Meditari Accountancy Research dan jurnal lainnya masing-masing 1 jurnal.

Tabel 1 Ranking Jurnal Berdasarkan Jurnal yang Terindeks Scopus

\begin{tabular}{|c|c|c|c|}
\hline Title & $\begin{array}{l}\text { Journal } \\
\text { Rangkings } \\
\text { /Quartiles }\end{array}$ & Publishers & Country \\
\hline $\begin{array}{l}\text { Accounting, Auditing and } \\
\text { Accountability Journal }\end{array}$ & Q1 & $\begin{array}{l}\text { Emerald Group } \\
\text { Publishing Ltd }\end{array}$ & $\begin{array}{l}\text { United } \\
\text { Kingdom }\end{array}$ \\
\hline Accounting Forum & Q1 & Elsevier Ltd & $\begin{array}{l}\text { United } \\
\text { Kingdom }\end{array}$ \\
\hline Ecology Economics & Q1 & Elsevier BV & Netherlands \\
\hline $\begin{array}{l}\text { Economics of Eduation } \\
\text { Review }\end{array}$ & Q1 & Elsevier Ltd & $\begin{array}{l}\text { United } \\
\text { Kingdom }\end{array}$ \\
\hline Educational Psycologist & Q1 & $\begin{array}{l}\text { Lawrence } \\
\text { Erlbaum } \\
\text { Associatites } \\
\text { Inc }\end{array}$ & United States \\
\hline $\begin{array}{l}\text { Journal of Accounting } \\
\text { Research }\end{array}$ & Q1 & $\begin{array}{l}\text { Blackwell } \\
\text { Publishing Inc. }\end{array}$ & $\begin{array}{l}\text { United } \\
\text { Kingdom }\end{array}$ \\
\hline $\begin{array}{l}\text { Journal of } \quad \text { Business } \\
\text { Research }\end{array}$ & Q1 & Elsevier BV & Netherlands \\
\hline $\begin{array}{l}\text { Naval Research Logistics } \\
\text { (NRL) }\end{array}$ & Q1 & $\begin{array}{l}\text { John Wiley \& } \\
\text { Sons Inc }\end{array}$ & United States \\
\hline $\begin{array}{l}\text { Business Communication } \\
\text { Quarterly }\end{array}$ & Q2 & $\begin{array}{l}\text { SAGE } \\
\text { Publications }\end{array}$ & United States \\
\hline $\begin{array}{ll}\text { International } & \text { Journal of } \\
\text { Accounting } & \text { Information } \\
\text { System } & \end{array}$ & Q2 & Elsevier Ltd & $\begin{array}{l}\text { United } \\
\text { Kingdom }\end{array}$ \\
\hline $\begin{array}{l}\text { Meditary Accountancy } \\
\text { Research }\end{array}$ & Q2 & $\begin{array}{l}\text { Emerald Group } \\
\text { Publishing Ltd }\end{array}$ & $\begin{array}{l}\text { United } \\
\text { Kingdom }\end{array}$ \\
\hline
\end{tabular}




\begin{tabular}{|c|c|c|c|}
\hline Title & $\begin{array}{c}\text { Journal } \\
\text { Rangkings } \\
\text { /Quartiles } \\
\end{array}$ & Publishers & Country \\
\hline $\begin{array}{l}\text { Social and Environment } \\
\text { Accountability Journal }\end{array}$ & Q2 & Routledge & United States \\
\hline Accounting and Finance & Q3 & $\begin{array}{l}\text { Wiley- } \\
\text { Blackwell }\end{array}$ & United States \\
\hline $\begin{array}{l}\text { Advances in International } \\
\text { Accounting }\end{array}$ & Q3 & JAI Press & United States \\
\hline $\begin{array}{l}\text { Asian Review of } \\
\text { Accoutning }\end{array}$ & Q3 & $\begin{array}{l}\text { Emerald Group } \\
\text { Publishing Ltd }\end{array}$ & $\begin{array}{l}\text { United } \\
\text { Kingdom }\end{array}$ \\
\hline $\begin{array}{l}\text { International Journal of } \\
\text { GEOMATE }\end{array}$ & Q3 & $\begin{array}{l}\text { GEOMATE } \\
\text { International } \\
\text { Society }\end{array}$ & Japan \\
\hline Managerial Finance & Q3 & $\begin{array}{l}\text { Emerald Group } \\
\text { Publishing Ltd }\end{array}$ & $\begin{array}{l}\text { United } \\
\text { Kingdom }\end{array}$ \\
\hline $\begin{array}{l}\text { Accounting Historians } \\
\text { Journal }\end{array}$ & Q4 & $\begin{array}{l}\text { Academy of } \\
\text { Accounting } \\
\text { Historians }\end{array}$ & United States \\
\hline $\begin{array}{l}\text { Corporate Ownership and } \\
\text { Control }\end{array}$ & Q4 & $\begin{array}{l}\text { Virtus } \\
\text { Interpress }\end{array}$ & Ukraine \\
\hline $\begin{array}{l}\text { Review of Accounting } \\
\text { nad Finance }\end{array}$ & Q4 & $\begin{array}{l}\text { Emerald Group } \\
\text { Publishing Ltd }\end{array}$ & $\begin{array}{l}\text { United } \\
\text { Kingdom }\end{array}$ \\
\hline
\end{tabular}

Pada tabel 1 menunjukkan terdapat 20 jenis jurnal (20\%) yang telah terindeks scopus dari total 100 sampel jurnal yang terpublikasi tentang akuntansi nilai tambah syariah/Value Added, rangking jurnal diambil berdasarkan Scimago Journal \& Country Rank dan dikategorikan berdasarkan 4 quartiles (Q1, Q2, Q3, dan Q4), dimana rangking jurnal diurutkan dari yang paling tinggi (Q1) sampai rangking yang paling rendah (Q4).

Tabel 2 Ranking Jurnal Berdasarkan SINTA-Science and Technology Index

\begin{tabular}{lcl}
\hline \multicolumn{1}{c}{ Journal name } & $\begin{array}{c}\text { Sinta } \\
\text { Score }\end{array}$ & \multicolumn{1}{c}{ Publishers } \\
\hline $\begin{array}{l}\text { Al Iqtishod: Jurnal Ilmu Ekonomi Syariah } \\
\text { (Journal of Islamic Economics) }\end{array}$ & S2 & $\begin{array}{l}\text { UIN } \\
\text { Hidayatullah } \\
\text { Jakarta }\end{array}$ \\
$\begin{array}{l}\text { Ikonomika: Jurnal Ekonomi dan Bisnis } \\
\text { Islam }\end{array}$ & S2 & $\begin{array}{l}\text { UIN Raden Intan } \\
\text { Lampung } \\
\text { Universitas }\end{array}$ \\
$\begin{array}{l}\text { Jurnal Akuntansi dan Keuangan Indonesia } \\
\text { Journal of Indonesian Economy and }\end{array}$ & S2 & $\begin{array}{l}\text { Indonesia } \\
\text { Universitas Gadjah } \\
\text { Media Riset Akuntansi, Auditing \& \& }\end{array}$ \\
$\begin{array}{l}\text { Informasi } \\
\text { Mada }\end{array}$
\end{tabular}




\begin{tabular}{|c|c|c|}
\hline Journal name & $\begin{array}{l}\text { Sinta } \\
\text { Score }\end{array}$ & Publishers \\
\hline Jurnal Riset Akuntansi dan Keuangan & S3 & $\begin{array}{l}\text { Unversitas } \\
\text { Pendidikan } \\
\text { Indonesia }\end{array}$ \\
\hline $\begin{array}{l}\text { Tazkia Islamic Finance } \& \text { Business } \\
\text { Review }\end{array}$ & S3 & STEI Tazkia \\
\hline Accounting Analysis Journal & S4 & $\begin{array}{l}\text { Universitas Sebelas } \\
\text { Maret }\end{array}$ \\
\hline Fokus Ekonomi: Jurnal Ilmiah Ekonomi & S4 & $\begin{array}{ll}\text { STIE } & \text { Pelita } \\
\text { Nsuantara } & \\
\text { Semarang } & \\
\text { Unversitas } & \end{array}$ \\
\hline Jurnal ASET (Akuntansi Riset) & S4 & $\begin{array}{l}\text { Pendidikan } \\
\text { Indonesia }\end{array}$ \\
\hline Jurnal Dinamika Ekonomi dan Bisnis & S5 & $\begin{array}{l}\text { Universitas Islam } \\
\text { Nahdlatul Ulama } \\
\text { Universitas }\end{array}$ \\
\hline Media Ekonomi & S5 & $\begin{array}{l}\text { Muhammadiyah } \\
\text { Purwokerto }\end{array}$ \\
\hline
\end{tabular}

Sumber: Penulis

Dari 100 sampel jurnal yang terpublikasi tentang akuntansi nilai tambah syariah/Value Added, 12 jenis jurnal (12\%) yang terindeks SINTA (Science and Technology Index) - Ristekdikti (Kementerian Riset, Teknologi, dan Pendidikan Tinggi Republik Indonesia). Tabel 3.2 menunjukan rangking jurnal berdasarkan Sinta score yang dikategorikan berdasarkan (S1, S2, S3, S4, S5 dan S6) dimana rangking jurnal diurutkan dari yang paling tinggi Sinta-1/(S1) sampai rangking yang paling rendah Sinta-6/(S6).

\subsection{PERIODESASI PERKEMBANGAN RISET AKUNTANSI NILAI TAMBAH SYARIAH}

Gambar 3 menunjukkan daftar publikasi jurnal berdasarkan periodisasi perkembangan akuntansi nlai tambah (Value Added). Pengelompokan bertujuan untuk melihat lebih detail sejauh mana perkembangan 25 tahun teakhir, dari periode tahun 1994 sampai 2018.

Gambar 1 Perkembangan Periodesasi Riset Nilai Tambah syariah

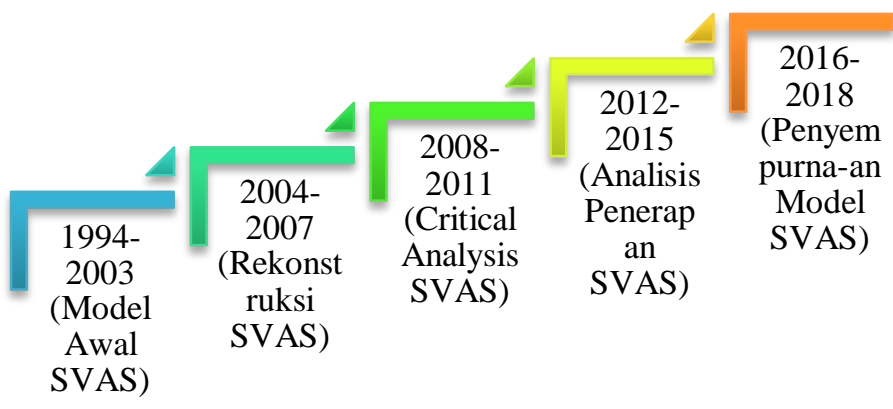




\subsubsection{Tahun 1994-2003 (Model Awal SVAS)}

Dari hasil observasi terhadap 100 artikel jurnal pilihan yang terpublikasi, perkembangan awal pada periode awal tahun (1994-2003) dikelompokan kedalam model awal berkembangnya riset penelitian Sharia Value Added Statement (SVAS), pada periode ini terdapat beberapa penelitian yang mengusulkan beberapa model pelaporan Value Added yang sesuai dengan perusahaan berlabel syariah. Antara lain Baydoun \& Willett (1994 \& 2000) dalam penelitiannya yang berjudul "Islamic Corporate Reports", dalam mengimplementasikan laporan nilai tambah pada entitas syariah Nabil Baydoun dan Roger Willet menambahkan beberapa akun untuk disesuaikan dengan entitas syariah.

Pengembangan laporan keuangan syari'ah dilakukan Baydoun dan Willett dengan usulannya Islamic Corporate Report's (ICR's). ICR's terdiri dari Laporan Nilai Tambah, Neraca Berbasis Nilai Sekarang dan Laporan Arus Kas. ICR's menurut Baydoun dan Willett dikembangkan atas dasar manfaat pragmatis (memberikan jalan keluar organisasi Islam yang beroperasi di lingkungan non-Islam) dan adaptif (adaptasi praktik akuntansi Barat).

Selanjutnya Sulaiman (2001) "Testing a Model of Islamic Corporate Financial Reports" Menguji model laporan Islamic Corporate Report's Baydoun dan Willett melalui survei kuesioner dan laboratory experiment. Hasilnya, tidak menemukan perbedaan dalam persepsi kegunaan antara responden Muslim dan non-Muslim. Yang kemudian dalam penelitian lainnya mengembangkannya dan mengajukan usulan pentingnya akun sosial dan lingkungan berbasis etika syari'ah, dengan berbentuk laporan tambahan (voluntary disclosure).

Kemudian Triyuwono tahun (2001) dalam penelitiannya yang berjudul "Metafora Zakat dan Shari'ah Enterprise Theory Sebagai Konsep Dasar dalam Membentuk Akuntansi Syari'ah" mengajukan konsep "metafora amanah" yang kemudian diturunkan menjadi "realitas organisasi yang dimetaforakan dengan zakat" (zakat metaphorised organisational reality) atau, singkatnya, "metafora zakat". Usulannya dengan konsep ini, perusahaan tidak lagi berorientasi pada profit (profit-oriented), tetapi berorientasi pada zakat (zakat-oriented). Menggunakan konsep nilai zakat sebagai dasar operasi manajemen dan konstruksi akuntansi syari'ah.

Harahap tahun (2003) dalam penelitiannya "The Disclosure of Islamic Values -Annual Report. The Analysis of Bank Muamalat Indonesia's Annual Report" menanggapi munculnya akuntansi nilai tambah pelaporan karyawan, akuntansi sosial ekonomi, dan akuntansi lingkungan, memperkuat bukti dari kekurangan sistem akuntansi kapitalistik dalam membangun prinsip-prinsip yang adil diantara para pemangku kepentingan perusahaan. Dalam penelitian ini menguji islamic values pada laporan tahunan Bank Muamalat Indonesia, hasilnya berpendapat bahwa BMI telah menggunakan standar akuntansi kapitalistik, sistem dalam pengungkapannya digunakan tidak memberikan indikasi keadilan dan tidak sesuai dengan nilai Islam dan 
menyarankan beralih dari penggunaan praktik kapitalistik terutama berkaitan dengan pengungkapan dan indikator keuangan menuju sistem yang mempertimbangkan praktik keadilan dan etika.

Dari beberapa penelitian tersebut diatas para peneliti memberikan model-model bentuk pelaporan yang ditawarkan sebagai konsep dasar SVAS dan memperkuat konsep ini harus diterapkan.

\subsubsection{Tahun 2004-2007 (Rekonstruksi SVAS)}

Periode tahun (2004-2007) dikelompokan kedalam rekonstruksi SVAS, pada rentang tahun tersebut terdapat beberapa penelitian yang merekonstruksi ulang konsep Value Added statement antara lain Mook, L. tahun (2006), Dalam penelitiannya "Integrating and Reporting an Organisation's Economic, Social and Environmental Performance. The Expanded Value Added Statement", dalam penelitian ini peneliti merekonstruksi VAS dan menyajikan model baru yaitu akuntansi sosial yang disebut Expanded Value Added Statement (EVAS), yang melaporkan nilai ekonomi, sosial dan lingkungan, dimana pelaporannya ditambahkan khusus dalam satu laporan yang terintegrasi. Pengembangan model ini diasumsikan bahwa akuntansi adalah sebagai agen perubahan eksplisit untuk menggerakkan organisasi/perusahaan menuju keberlanjutan.

Tahun (2007) Mulawarman, Triyuwono, \& Ludigdo, dalam penelitiannya yang berjudul "Rekonstruksi Teknologi Integralistik Akuntansi Syari'ah: Shari'ate Value Added Statement”, Rekonstruksi dalam penelitian ini merupakan proses perubahan materialitas Value Added Statement (VAS) dan Expanded Value Added Statement (EVAS) menjadi SVAS yang bersifat finansial-sosial-lingkungan dan materialmental-spiritual. SVAS merupakan bentuk teknologi (laporan) kinerja keuangan berdasarkan nilai Islam dan tujuan syari'ah dengan zakat sebagai pusatnya. Konsep utama lainnya dalam penelitian ini adalah: (1) bahwa sumber nilai tambah dalam pernyataan nilai tambah syariah harus diperoleh berdasarkan perintah Tuhan (halal, thoyib dan menghilangkan riba), dan (2) distribusi dari nilai tambah harus didasarkan pada Mashlaha dan 'Adalah (keadilan).

Penelitian lainnya, Triyuwono "Mengangkat "Sing Liyan" Untuk Formulasi Niai Tambah Syari'ah" didalam studinya menjelaskan rekonstruksi dengan memformulasikan nilai tambah syari'ah dengan adopsi Shri'ah Enterprise Theory (SET) sebagai dasar Teori Akutansi Syari'ah. Hasil studi ini menunjukkan bahwa nilai tambah syari'ah meliputi nilai ekonomi (moneter), mental dan spiritual. Nilai tambah ekonomi adalah nilai tambah yang dapat diukur dengan cara moneter, sedangkan nilai mental dan spiritual tidak dapat diukur dengan cara demikian. Nilai tambah syar'ah meliputi semua nilai tambah (ekonomi, mental, spiritual) yang dibutuhkan, diproses dan didistribusikan secara halal. Dari pemaparan para peneliti diatas dapat disimpulkan pada periode ini peneliti banyak merekonstruksi ulang konsep nilai tambah yang benar-benar pas untuk konsep SVAS yang sesuai dengan syariat islam. 


\subsubsection{Tahun 2008-2011 (Critical Analysis SVAS)}

Periode Tahun (2008-2011) pada rentang tahun ini dikelompokan kedalam analisis kritik terhadap Value Added Statement (VAS) dimana pada periode ini terdapat beberapa penelitian yang mencoba mengkaji ulang terhadap konsep VAS, antara lain Mandal \& Goswami (2008), "Value Added Statement (VAS) - a Critical Analysis Purpose of the Study”, dalam penelitian ini mencoba menunjukkan bagaimana dan sampai sejauh mana VAS dapat melengkapi laporan keuangan tambahan, untuk memuaskan semua pemangku kepentingan perusahaan. Studi kasus penelitian ini pada perusahaan Bharat Heavy Electricals Limited dan mengukur kinerja, produktivitas, target laba dan hubungan antara variabel yang bersangkutan mengunakan Time Series Analysis, Analisis Regresi dan Analisis Rasio.

Hasil studi ini menunjukkan VAS memberikan informasi keuangan dengan cara yang lebih baik dan sangat berguna untuk menilai kinerja dan produktivitas suatu perusahaan untuk pengambilan keputusan manajerial. Tetapi disisi lain meskipun VAS sangat berguna untuk menilai kinerja dan produktivitas suatu perusahaan (Publik atau Swasta) untuk pengambilan keputusan manajerial, tetapi sangat sulit diterapkan dan menggeser konsep kuno yang sudah mengakar kuat.

Selanjutnya Mulawarman (2009b), dengan penelitiannya yang berjudul "Menggagas Laporan Keuangan Syari'ah Berbasis Trilogi Ma'isyah-Rizq-Maal”. Perumusan dalam penelitian dilakukan dengan memanfaatkan metodologi dua langkah tazkiyah. Langkah pertama konsep konvensional dari laporan keuangan dan Baydoun dan Willett's 1994 \& 2000 Islamic Corporate Report disempurnakan oleh Akuntansi Syariah (berasal dari Nilai-Nilai Islam dan Maqashid Asy-Syari'ah). Langkah kedua, hasilnya kemudian disempurnakan oleh Technosystem (Islam) dan Structuralism Constructivist untuk menghasilkan Laporan Keuangan Syariah.

Hasil pertama menunjukkan bahwa trilogi ma'isyah-rizq-maal adalah substansi dari laporan keuangan syariah. Ma'isyah adalah representasi dari transaksi bisnis Islami. Rizq adalah representasi dari penciptaan nilai tambah Islami. Maal adalah representasi kekayaan Islam. Konsekuensi dari hasil pertama menunjukkan bahwa perumusan: (1) laporan arus kas syariah didasarkan pada konsep ma'isyah; (2) pernyataan nilai tambah syariat didasarkan pada konsep rizq; dan (3) neraca syariah didasarkan pada konsep maal.

Saputro \& Triyuwono (2009), “Koreksi Konsep Nilai Tambah Syari'ah: Menimbang Pemikiran Konsep Dasar Teoritis Laporan Keuangan Akuntansi Syari'ah" Penelitian ini dilakukan untuk melihat secara kritis konsep nilai tambah Syariah. Penelitian ini menggunakan pendekatan kualitatif dengan menganalisis dan mengkritik objek kritik, dengan indikator (etika Islam dalam muamalah, konsep distribusi pendapatan, dan prinsip kesederhanaan). Hasil dari penelitian ini menunjukkan bahwa ada beberapa bagian dari konsep nilai tambah yang berpotensi kontra produktif terhadap pengembangan akuntansi syariah. Konsep nilai tambah memiliki kemungkinan untuk menghasilkan realitas yang memiliki beberapa potensi: 
1) Definisi nilai tambah berpotensi menjadi bibit munculnya nilai kapitalisme melalui etika utilitarianisme, 2) Nilai tambah memiliki konsep distribusi pada kalangan terbatas, dan 3) Secara praktik dalam beberapa kasus, konsep dan format laporan nilai tambah belum menunjukkan kemudahan dalam muamalah sesuai dengan aturan syari'at Islam.

\subsubsection{Tahun 2012-2015 (Analisis Penerapan SVAS)}

Perkembangan riset pada rentang periode tahun (2012-2015) dikelompokan kedalam analisis penerapan SVAS, dimana terdapat banyak penelitian yang membandingkan konsep income statement dengan Value Added statement dalam sebuah institusi/perusahaan. Beberapa penelitiannya antara lain: penelitian Prasetya tahun (2013) yang berjudul "Financial Performance Difference Analysis of Mandiri Islamic Bank by Using Sharia Value Added and Income Statement Approach on 2007-2011 Period" hasil penelitiannya menyimpulkan bahwasannya kinerja keuangan Bank Syariah Mandiri diwakili oleh rasio BOPO menunjukkan bahwa tidak ada perbedaan yang signifikan dalam pendekatan laporan laba rugi dan pendekatan pernyataan nilai tambah syariah. Sedangkan dari segi tingkat profitabilitas miliki perbedaan yang signifikan, laba yang diukur menggunakan SVAS diperoleh lebih tinggi dibandingkan dengan laba yang diperoleh berdasarkan pendekatan laporan laba rugi.

Kartika \& Kristianto (2013), “Analisis Kinerja Keuangan Bank Muamalat Indonesia Dengan Menggunakan Pendekatan Laba Rugi dan Nilai Tambah (Survei Pada PT Bank Muamalat Indonesia)", pada penelitian ini menghasilkan kesimpulan bahwa terdapat perbedaan yang signifikan antara perolehan rasio kinerja keuangan PT Bank Muamalat Indonesia yang dihitung antara pendekatan laporan laba rugi dengan pendekatan SVAS, disebabkan adanya perbedaan konstruksi dan konsep dari teori akuntansi kedua metode tersebut. Pendekatan SVAS lebih baik dari pendekatan Laporan Laba Rugi, sebab pendekatan SVAS menghasilkan nilai rasio kinerja yang lebih besar dari Laporan Laba Rugi. Begitupun hasil penelitian lainnya antara lain Rifai 2013, Fauzi 2012, Istikhanah \& Achadiyah 2014, tahun 2015 Rosmanidar, dan Fahriani hasil dari seluruh penelitian menyimpulkan rasio kinerja diukur dengan konsep SVAS lebih besar dibandingkan Laba Rugi.

\subsubsection{Tahun 2016-2018 (Penyempurnaan Model SVAS)}

Terakhir periode tahun (2016-2018) pada rentang tahun tersebut dikelompokan kedalam penyempurnaan konsep model SVAS, terdapat beberapa peneliti memberikan sebuah konsep baru dalam laporan nilai tambah. Penelitiannya atara lain Mulawarman (2016) memberikan sebuah model baru dalam penelitiannya yang berjudul "Menggagas Neraca Syari'Ah Berbasis Maal: Kontekstualisasi 'Kekayaan Altruistik Islami”. Penelitian ini merumuskan bentuk konsep baru yaitu Neraca Syariah, hasil dari penelitian ini menunjukkan bahwa maal adalah bentuk kekayaan Islam dan Altruistik. Ini berarti bahwa kekayaan harus: (1) memiliki nilai-nilai holistik (material, mental dan spiritual); (2) dimiliki oleh pemangku kepentingan yang lebih 
luas (Allah, langsung, tidak langsung, dan alam); dan (3) berdasarkan caracara syari'at (halal, thoyib dan bebas dari riba). Konsekuensi dari hasil utama adalah semua elemen dalam Neraca Syariah berdasarkan pada: (1) ketaatan (abd'Allah) aset, kewajiban dan ekuitas, dan (2) kreativitas (khalifatullah fil ardh) aset, kewajiban, dan ekuitas.

Tahun (2018) Amerieska, dalam penelitiannya yang berjudul "Pelaporan Keuangan Organisasi Nirlaba: Rekonstruksi Sharia Value Added Statement Berbasis Amanah”. Penelitian ini melakukan analisis penyusunan laporan keuangan pada oraganisasi nirlaba dengan merekonstruksi laporan keuangannya berdasarkan Pernyataan Standar Akuntansi Keuangan (PSAK) Nomor 45 dengan Shariah Value Added Statement.

Pada penelitian ini diusulkan sebuah konsep laporan nilai tambah yang berbasis shariah pada yayasan amil zakat. Makna nilai tambah pada organisasi niurlaba berbeda dengan organisasi profit, organisasi profit dasar distribusi nilai tambah berdasarkan income, sedangkan pada organisasi nirlaba konsep nirlaba didasarkan pada akuntabilitas pengelolaan dana. Shariah Value Added Statement memberikan alternatif penyampaian informasi keuangan.

\section{KESIMPULAN}

Analisis terhadap 100 sampel artikel jurnal yang terpublikasi tahun 19942018 terkait akuntansi nilai tambah syariah/Value Added. Terdapat banyak keragaman pembahasan jurnal terkait akuntansi nilai tambah syariah/Value Added yang terpublikasi setelah diobservasi. Jumlah publikasi artikel jurnal terbanyak yaitu pada tahun tahun 201610 jurnal (10\%) dari 100 sampel artikel jurnal terpublikasi. Umumnya penggunaan jenis penelitian yang terbanyak digunakan dari artikel jurnal-jurnal yang terpublikasi baik jurnal nasional ataupun internasional terkait Value Added/akuntansi nilai tambah syariah selama perode tahun 1994 hingga 2018 yaitu jenis penilitian deskriptif 44 artikel jurnal (44\%). kemudian jenis penilitian eksperimental 30 artikel jurnal $(30 \%)$ dan yang menggunakan penelitian eksploratif sebanyak 26 jurnal (26\%). (c) Secara umum dari 100 sampel artikel jurnal penelitian, pendekatan metode penelitian yang terbanyak digunakan adalah pendekatan kualitatif sejumlah 56 artikel jurnal (56\%), kemudian penelitian dengan pendekatan kuantitatif sejumlah 42 artikel jurnal (42\%) dan jurnal yang menggunakan pendekatan kombinasi (mix method) sejumlah 2 artikel jurnal $(2 \%)$.

Subjek pembahasan terkait artikel jurnal akuntansi nilai tambah syariah terbanyak yaitu Value Added Statement/Reporting (54\%) kemudian subjek pembahsan mengenai Value Added (22\%), kemudian subjek pembahasan institusi (15\%), dan pembahsan subjek paling sedikit yatu tentang manajemen (9\%). Indonesia, United States, United Kingdom dan Afrika Selatan menjadi area studi terbanyak terkait penelitian Value Added dari 100 sampel artikel jurnal dibandingkan dengan negara lainnya. Dari segi 
area publikasi artikel jurnal, Indonesia, United States, United Kingdom, India dan Belanda menjadi area publikasi terbanyak dibandingkan negara lainnya. Terdapat lebih dari 50 jenis jurnal dalam penelitian ini. Diantaranya 20 jenis jurnal (20\%) yang telah terindeks scopus dan 12 jenis jurnal $(12 \%)$ yang terindeks SINTA (Science and Technology Index) - Ristekdikti (Kementerian Riset, Teknologi, dan Pendidikan Tinggi Republik Indonesia).

Periodesasi perkembangan riset akuntansi nilai tambah syariah dibagi menjadi lima tahapan perkembangan (1) 1994-2003 (Model Awal SVAS), (2) 2004-2007 (Rekonstruksi SVAS), (3) 2008-2011 (Critical Analysis SVAS), (4) 2012-2015 (Analisis Penerapan SVAS), dan (5) 2016-2018 (Penyempurna-an Model SVAS). Hasil dari analisis diatas dapat diketahui bahwasannya isu akuntansi nilai tambah syariah menjadi pembahasan yang intensif bagi para pakar-pakar muslim dari tiap tahun ke tahun. Hal ini merupakan persoalan yang dihadapi setiap negara terkait konsep berkeadilan seperti apa yang semestinya dapat diterapkan untuk seluruh perusahaan, supaya dapat seimbangnya antara nilai perusahaan, bumi, maupun para pemangku kepentingan lainnya. Konsep SVAS terus berkembang seiring waktu berjalan begitupun belum adanya aturan baku yang mewajibkan penerapannya.

\section{DAFTAR PUSTAKA}

Adnan, M. A. (1997). The Shariah, Islamic Banks and Accounting Concepts. Indonesian Journal of Accounting and Auditing, 1(1), 47-80.

Amerieska, S. (2018). Pelaporan Keuangan Organisasi Nirlaba: Rekonstruksi Sharia Value Added Statement Berbasis Amanah. El Muhasaba: Jurnal Akuntansi, 8(1), 16. https://doi.org/10.18860/em.v8i1.4955

Baydoun, N., \& Willett, R. J. (1994). Islamic accounting theory. In The AAANZ Annual Conference.

Baydoun, N., \& Willett, R. J. (2000). Islamic Corporate Reports. Abacus: A Journal of Accounting, Finance and Business Studies, 26(1), 71-90.

Harahap, S. S. (2001). Mепији Perumusan Teori Akuntansi Islam. Jakarta: Pustaka Quantum.

Harahap, S. S. (2003). The Disclosure Of Islamic Values - Annual Report The Analysis Of Bank Muamalat Indonesia's Annual Report. IQTISAD Journal of Islamic Economics, 3(1), 35-45.

Kartika, P., \& Kristianto, D. (2013). Analisis Kinerja Keuangan Bank Muamalat Indonesia Dengan Menggunakan Pendekatan Laba Rugi dan Nilai Tambah (Survei Pada PT Bank Muamalat Indonesia). Jurnal Ekonomi Dan Kewirausahaan, 13(2), 193-203.

Mandal, N., \& Goswami, S. (2008). Value Added Statement (VAS) - A Critical Analysis. Great Lakes Herald, 2(3), 98-120. 
Mook, L. (2006). Integrating and Reporting an Organisation's Economic, Social and Environmental Performance. The Expanded Value Added Statement. Sustainability Accounting and Reporting, 12, 281-282.

Mulawarman, A. D. (2009a). Akuntansi Syariah Teori, Konsep dan Laporan Keuangan. Jakarta: E Publishing Company.

Mulawarman, A. D. (2009b). Menggagas Laporan Keuangan Syari'ah Berbasis Trilogi Ma'isyah-Rizq-Maal. Tazkia Islamic Finance \& Business Review, 4(1), 1-21.

Mulawarman, A. D. (2016). Menggagas Neraca Syari'Ah Berbasis Maal: Kontekstualisasi ' Kekayaan Altruistik Islami”. Jurnal Akuntansi Dan Keuangan Indonesia, 4(2), 169-192. https://doi.org/10.21002/jaki.2007.09

Mulawarman, A. D., Triyuwono, I., \& Ludigdo, U. (2007). Rekonstruksi Teknologi Integralistik Akuntansi Syari'Ah: Shari'Ate Value Added Statement. Jurnal Akuntansi Dan Keuangan Indonesia, 4(1), 1-24.

Naswandi, C. (2009). Pengungkapan Pelaporan Keuangan Dalam Perspektif Signalling Theory. Kajian Akuntansi, 1(1), 48-57.

Saputro, A. S., \& Triyuwono, I. (2009). Koreksi Konsep Nilai Tambah Syari'ah: Menimbang Pemikiran Konsep Dasar Teoritis Laporan Keuangan Akuntansi Syari'ah. Proceeding Simposium Nasional Akuntansi XII Unsri Palembang (6-9 November), 1-25.

Serdarmayanti, \& Hidayat, S. (2011). Metodologi Penelitian (2nd ed.). Bandung: Mandar Maju.

Subana, \& Sudrajat. (2005). Dasar - Dasar Penelitian Ilmiah. Bandung: Pustaka Setia.

Sulaiman, M. (2001). Testing a Model of Islamic Corporate Financial Reports : IIUM Journal of Economic and Management, 2(2), 115-140.

Suyudi, M. (2010). Sustainability Reporting Konsep Quardrangle Bottom Line ( Qbl ) Dimensi Environmental Performance. Jurnal Eksis, 6(2), 1537-1549.

Triyuwono, I. (2001). Metafora Zakat dan Shari'ah Enterprise Theory Sebagai Konsep Dasar dalam Membentuk Akuntansi Syari'ah. Indonesian Journal of Accounting and Auditing, 5(2), 131-145.

Triyuwono, I. (2007). Mengangkat "Sing Liyan" Untuk Formulasi Niai Tambah Syari'ah. Simposium Nasional Akuntansi X, 1-21. https://doi.org/http://dx.doi.org/10.18202/137

Yogesha, B. ., \& Mahadevappa, D. B. (2014). Analysis of Value Added Ratios of Indian Oil Corporation Ltd. IOSR Journal of Humanities and Social Science, 19(11), 18-25. https://doi.org/10.9790/0837191151825 
